\title{
ВОЗМОЖНОСТЬ ПЕРСОНАЛИЗИРОВАННОГО ИСПОЛЬЗОВАНИЯ ЦИТОФЛАВИНА В КАЧЕСТВЕ ЦИТОПРОТЕКТОРА ПРИ ИШЕМИЧЕСКОЙ БОЛЕЗНИ СЕРДЦА
}

\section{О. В. Ромащенко 1}

Проведено обслсдованис 30 пациентов с ишемической болезнью сердца: стабильной стенокардией напряжения I - III функционального класса с сопутствующей гипертонической болсзнью и хронической сердечной недостаточностью. Для определения цитопротскторной активности цитофлавина исследовали лсйкоциты крови больных в условия in vitro методом флуоресцентной микроскопии при помоши инвертированного флуоресцентного микроскопа EclipseTi-U (Nikon, Япония). Путём окрашивания лейкоцитов флуоресцентными красителями (кальцеин АМ, этидия бромид) определяли живые и погибшие клетки, рассчитывали индекс жизнеспособности клеток. При введении цитофлавина в пробу с лейкоцитарной взвесью наблюдали 2 варианта изменения жизнеспособности клеток: у $80 \%$ больных он повысился, в среднем, на $60 \%$ $(p<0,001)$ и у $20 \%$ пашиентов - снизился, в срсднсм, на $47 \%(p<0,1)$. Показано, что цитофлавин гроявляет цитопротекторную активность у пациентов с ишемической болсзнью сердца при наличии индивидуальной фармакодинамической мишени для действия данного препарата: признаков разрушения миоцитов скелетных мышц и сердца, нарушения функции почек, системной гипоксии на фоне нормального уровня липидов в крови, сохранной функции печени, первой степени артериальной гипсртензии и фазы активации функциональной системы адаптации человека, что определяет возможность персонализированного использования данного лекарственного препарата при ишемической болезни сердца.

Ключевые с.лова: цитоф:Іавин; лейкоциты; жизнеспособность; ишемическая болезнь сердца; пациснты; микроскопия; in vitro; персонализированная фармакотерагіия.

\section{ВВЕДЕНИЕ}

Широкая распространённость и высокая смертность от ишемической болезни ссрдца (ИБС) в нашей стране и за рубсжом, несмотря на принятые стандарты лечения, определяют актуальность и необходимость поиска новых лекарственных комбинаций для более эффсктивного лечения данного заболевания $[15,17]$. Стратегия выбора лекарственных средств и их комбинаций при лечении пациентов с ИБС должна носить персонализированный характер, как обозначил экс-президент Европейского общсства кардиологов R. Ferrary, назвав такой подход “бриллиантовым” [18]. В Европейские и Российские рекомендации по лечению хронической ИБС включены некоторые препараты метаболического ряда [3, 17].

В наших предыдуших исследованиях было показано, что комплексный препарат метаболического ряла цитофлавин, прямым показанисм к назначению которого является ишемия головного мозга $[4,6,12]$, при некоторых условиях может оказывать цитопротекторный эффект и у пациентов с ИБС [9-11]. Среди таких условий нами бы.ти названы генные полиморфизмы

1 ФГАОУ ВПО “БелГородский государственный национальный исслсдовательскнй уннверситет", Россия, 308017, Белгород. ул. Победы. . 85. системы цитохрома Р450 (СҮР2С9) [10] и эндотелиальной синтазы окиси азота [9], а также условие сохранения адаптационных резервов жизнеспособности клеток [11], что для практической деятельности врача имеет весьма неопределённое значснис. В этой связи, мы решили разработать чёткие клинические критерии прогнозирования цитопротекторного эффекта цитофлавина у пациентов с ИБС.

Моделью для изучения жизнеспособности клеток явились лейкоциты крови больных, поскольку они могут отражать внутреннее состоянис организма и являются легкодоступным материалом для исследования. Эти иммуннокомпетентные клетки рассматриваются как своего рода "зеркало гомеостаза", по которому можно опрелелить характер процесса, лежащего в основе болезни, его тяжесть, прогноз и зффективность терапии [13]. W. Jinetal на основании ряда собственных исследований утверждают, что характер повреждений митохондрий в кардиомиоцитах и лейкоцитах псриферичсской крови идснтичсн, В лсйкоцитах отражаются изменения, происходящие в кардиомиоцитах, как “в зеркале" [16].

Целью настоящего исследования явилось определение возможности персонализированного использования цитофлавина у пациентов с ИБС на основании определения критериев прогнозирования цитопротек- 
торного свойства данного препарата при тестировании in vitro его влияния на жизнеспособность клеток.

\section{МЕТОДЫ ИССЛЕДОВАНИЯ}

Проведено исследование образцов крови 30 пациентов с ИБС: стабильной стенокардией напряжения I - III функционального класса с сопутствующей гипертонической болезнью и хронической сердечной недостаточностью (из исследования исключали острый коронарный синдром), поступивших в отделение кардиологии № 1 Белгородской областной клинической больницы Святителя Иоасафа с января по июнь 2019 года. В группе исследования оказались 20 женщин и 10 мужчин в возрасте от 49 до 81 года, средний возраст пациентов составил $66,0 \pm 2,0$ лет.

Взятие крови выполняли утром натощак в вакуумную пробирку с ЭДТА. Обязательным условием отбора пациентов для исследования было отсутствис рентгеновского излучения на протяжении как минимум 21 дня до забора крови ввиду известного разрушиительного действия рентгеновских лучсй на лейкоциты крови человека и способности бслых клсток крови к полному обновлению состава на протяжении 21 дня при средней продолжительности жизни лейкоцитов 7-9 дней [14].

Лейкоциты крови (0,5 мл) отбирали вручную микропипеткой в асептичсских условиях, смешивали с 2 мл питательной срсды RPMI-1640 с глутамином (ПанЭко, Россия), затем помсшали в лунки 24-х луночного планшета по 20 мкл лсйкоцитарной суспензии в каждую лунку. Добавляли питательную среду и цитофлавин в количествс, нсобходимом для создания терапевтической концентрации прспарата в крови, эквивалентной разовой дозс цитофлавина 10 мл на 200 мл $0,9 \%$ раствора $\mathrm{NaCl}$ для внутривенного капельного введения. Руководствовались официальной инструкцисй по медицинскому применению цитофлавина [12]. Затем пробы инкубировали в теченис 3 ч (время, достаточнос для взаимодействия лекарства с клетками) в инкубаторе с $5 \%$ содержанием $\mathrm{CO}_{2}$ при температуре $37^{\circ} \mathrm{C}$. Через 3 ч инкубации из каждой лунки отбирали 500 мкл надосадочной жидкости и в оставшисся 500 мкл вносили флуоресцентные красители в конечной концентрации $1 \mathrm{nM} /$ мкл для кальцсина AM (Invitrogen, США), который окрашивает только жизнеспособные клетки и $2 \mathrm{nM} /$ мкл для этидия бромила (Sigma-Aldrich, CША), который окрашивает только мёртвые клетки [5]. Пробы снова ставили в термостат при тех же условиях сщё на 30 мин (время, достаточное для окрашивания клсток). При разработке схемы эксперимента руководствовались учебным пособием Е. В. Митрошиной и соавт. [7].

Результаты оценивали методом флуоресцентной микроскопии инвертированным микроскопом EclipseTi-U (Nikon, Япония). Обработку полученных данных проводили с помощью спсциализированного программного обеспечения EZ-Cl Free Viewer Ver 3.90
(Nikon). Осуществлялн позсяст мимества живых и погибини клеток, рассчитываты иесас тизнеспособности (ИЖ) клеток по форалле:

ИЖ $=\left(Z_{\text {живых клеток }}-Z_{\text {pon }}\right)\left(Z_{\text {mansens }}\right) \cdot 100$,

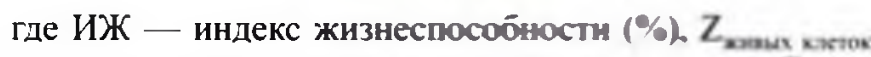
— количество живых клеток в 10 полех зрения; $Z_{\text {поги- }}$ ших клеток — количество попио̆ших кеток в 10 полях зрения.

По характеру измснения индекса хкизнеспособности под влиянием препарата. вводимого in vitro, судили о наличии цитопротекторных свойств цитофлавина по разработанному нами способ̆y [8]. Способ́ заключастся в опрелелснии ИЖ клеток в лунках с оценкой динамики данного показателя после введення лекарственного препарата in vitro. В случае. если при добавльнии в пробу лекарственного препарата в терапевтичсской концентрации ИЖ увеличивается, то это свидетельствует о наличии цитопротекторных свойств у данного лекарственного препарата. Снижснис ИЖ после введения лекарственного препарата свидетсльствует об отсутствии у последнего цитопротекторных свойств.

Всего было проанализировано 12000 клеток. Количественныс показатели оценивали на предмет соответствия нормальному распрсдслению с помощью теста Колмогорова-Смирнова. Для показателей, имеющих распрсдслснис близкос к нормальному, в дальнейшем осуществляли расчет срсднего арифметического значения, стандартного (срсднеквадратического) отклонения и ошиибки среднего, как отношения стандартного отклонсния к квалратному корню из количества анализирусмых значений. Результаты считали статистичсски значимыми при $p<0,05$.

Для определения критсрисв ирогнозирования цитопротекторного действия цитофлавина применяли статистический метод прогностического анализа Вальда.

Исследование проводили на базе лаборатории клеточных технологий НИИ фармакологии живых систем НИу "БелГУ".

\section{РЕЗУЛЬТАТЫ И ИХ ОБСУЖДЕНИЕ}

На рис. 1, а и $\sigma$ ноказаны микрофотографии живых и погибших клеток в полях зрения без внесения цитофлавина. ИЖ у пациентов с ИБС, в среднсм по групII (без внесения цитофлавина), составил $41 \%$. На рис. $2, a$ и б́ показаны микрофотографии живых и погибших клеток в полях зрения лунок, куда вносили цитофлавин в терапевтической конщентрации. ИЖ лсйкоцитов у пациентов с ИБС, в срсднсм по группе, после внесения цитофлавина существснно не изменился и составил $40 \%$.

Более детальный анализ динамики ИЖ показал 2 варианта изменения жизнеспособности клеток под влиянием цитоф:авина: у большинства (80\%) больных отмечсно увеличение жизнеспособности лейкоци- 


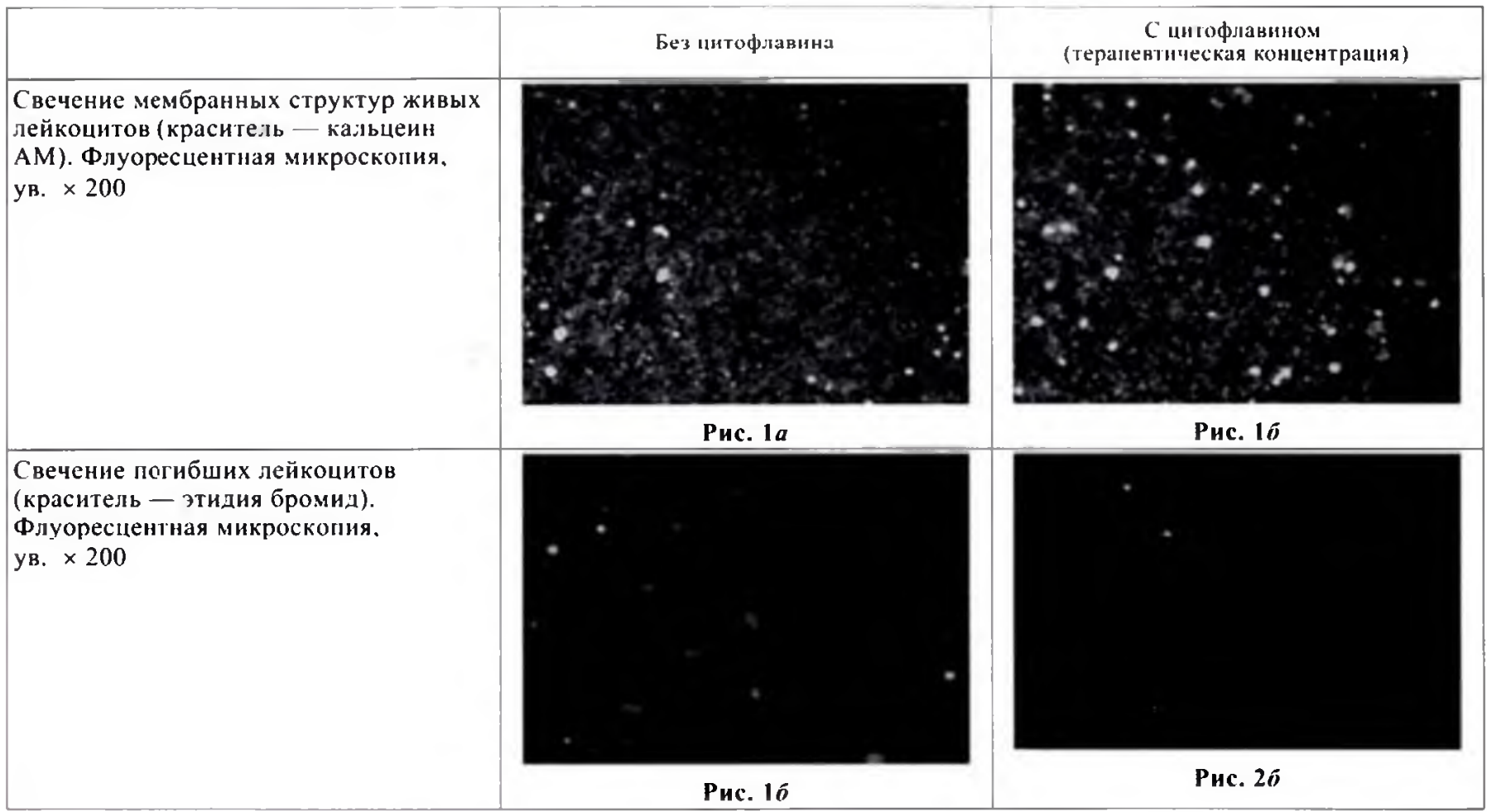

тов в среднем на $60 \%(p<0,001)$ и у $20 \%$ - тенденция к уменьшению данного показателя в срсднем на $47 \%(p<0,1)$.

Для выяснсния гричин обнаруженного явления вариативности изменения жизнеспособности клеток послс введсния цитофлавина в пробы с лейкоцитарной суспензисй пациентов с ИБС и определения прогностичсских критериев цитопротекторного эффекта данного препарата нами был проведен статистический прогностичсский анализ Вальда. Получили ряд наиболес значимых параметров исходного состояния больного, которые позволяют спрогнозировать рсакцию клеток (лейкоцитов крови) пациента на введсние цитофлавина (таблица).

По результатам нашего исслсдования цитопротекторная активность цитофлавина у пациснтов с ИБС зависит от ряда параметров исходного состояния больного и проявляется при следующих условиях: первая степень сопутствующей артериальной гипертензии; нормальный (невысокий) уровень лиги,јОв в крови общего холестерина в сывороткс крови (менее 3,4 ммоль/л), липопротеидов очень низкой плотности (менее 1,8 ммоль/л) и липопротеидов высокой плотности (менес 1.2 ммоль/л), признаки разрушения миоцитов и кардиомиоцитов (увеличение уровня КФК об̆ц. в крови болес $110 \mathrm{Eд/л} \mathrm{и} \mathrm{МВ-фракции} \mathrm{КФК} \mathrm{болес}$ $15 \mathrm{E \Omega} / \Omega$ ), норматьная функция печени (по уровню АЛТ менее $12.5 \mathrm{EJ} /$ ), признаки нарушения фуикции почек (повышение уровня мочевины - болес 8,3 ммоль/л н креатинина крови - болсс 115 мкмоль'. ). сникенное солержание гемоглобина в эритроцитах (менее 117 Г/л) как косвенный признак гиноксии органов и тканей и состоянис активации функциональной адаптационной системы чсловека (по данным общего анализа крови — появления базофилов болес $0,1 \cdot 10 \%$ / ).

Фенотипический профиль пациентов, у которых введение цитофлавина in vitro в терапевтической концентрации ассоциировалось со снижением жизнеспособности клеток, характеризуется: высокой степенью артериальной гипсртснзии, Іювышенным уровнем липидов крови, истопснисм функциональных резервов системы адаптации, нарушенной функцией печени Іри отсутствии признаков системной гипоксии, разрушения клеток ссрдца, скелетных мышц и почск.

Патогенстичсским обоснованием гравомочности полученных нами результатов и выводов являются слелуюпие тепретические попожения. Согласно официальной инструкции но мсдиицинскому применению цитофлавин является компјсксным ирепаратом метаболического ряда, который состонт из 4 компонентов - янтарной кислоты, инозина. рибофлавина и никотинамида [12]. Вхоляцис в состав препарата компонснты потенцируют антигипоксическое действия сукцината. Так, рибофјавин повышает активность сукцинатдегидрогеназы, инозин увеличивает обшее количество пуриновых нуклсотидіов, необходимых дія ресинтеза АТФ и ГТФ. Судя по механизму действия основных компонентов цитофлавина, данный препарат способен активировать аэробный гликолиз, т.е. кислород-зависимый процесс энсрі ообразования $[6,12]$. Соответственно, пчень важным условием проявления 
положительных свойств цитофлавина является сохранность доставки кислорода к тканям, что может наблюдаться только на начальных этапах развития ИБС. Полученные нами данные о цитопротекторных свойствах цитофлавина у пациентов с нормальным уровнем липидов крови косвенно могут свидетельствовать о существовании такого условия, поскольку процесс атеросклероза, приводящий к сужению сосудов, ассоциируется с уровнем липидов в крови [17]. Наши данные об эффективности цитофлавина в начальной фазе активации функциональной системы адаптации также свидетельствуют о возможности использования этого лекарственного препарата исключительно на начальном этапе формирования ИБС [2]. Важной находкой можно считать обнаруженное нами явление проявления цитопротекторных свойств цитофлавина у пациентов с признаками системной гипоксемии, разрушения миоцитов скелетных мышц, сердца и почек. По всей видимости, здесь идёт речь о нсобходимости наличия индивидуальной фармакодинамической мишени для действия метаболически активного препарата. Известно, что именно в сердце, скелетных мышцах, почках и печени наблюдаются наиболсе активные про- цессы энергообразования [1]. Oнсаншно. нмеет смысл восстанавливать энергетический обмен тола, когда он исходно нарушен и ассоцинруета с пювреждением тканей. Наше исследованне табте посазато важность сохранности функции печени ІІа проявления цитопротекторных свойств цитофтавнна, что, возможно, обусловлено особенностями б́нотрансформации этого препарата в печени.

Таким образом, гюказано, что препарат метаболического типа действия цитофтавин способ́ен улучшать жизнеспособность клеток и проявлять шитопротекторный эффскт у части больных НБС при условии наличия индивидуальной фармакодинамической мишени в виде повреждения клеток скелетных мышц, сердца, почек и преимущественно на начатьных этапах развития заболевания. Потенциальная возможность использования цитофлавина в комплексном лечении пациентов с ИБС нацеливает на расширение показаний к использованию данного лекарственного препарата.

\section{выводы}

1. При введении цитофлавина в терапевтической концентрации в пробу с лейкоцитарной взвесью, полу-

Прогностическая модель проявлення цитопротекторной активности интофлавина у пациентов с ИБС (по данным тестирования препаpata in vitro)

\begin{tabular}{|c|c|c|c|c|c|}
\hline № $n / n$ & Признак & ДиапазоІ1 & $\begin{array}{l}\text { Прогностический } \\
\text { козффициент }\end{array}$ & $\begin{array}{l}\text { Козффициент } \\
\text { информативности } \\
\text { (частный) }\end{array}$ & $\begin{array}{l}\text { Коэффичиент } \\
\text { информативности } \\
\text { (обший) }\end{array}$ \\
\hline \multirow[t]{2}{*}{1} & \multirow[t]{2}{*}{ Базофилы крови, $10^{9} / \Omega$} & $<0,1$ & -1 & 0,10 & \multirow[t]{2}{*}{0,80} \\
\hline & & or 0,1 & +7 & 0,70 & \\
\hline \multirow[t]{2}{*}{2} & \multirow[t]{2}{*}{ Степень артериальной гипсртензии } & 1 & +6 & 0,60 & \multirow[t]{2}{*}{0,69} \\
\hline & & 2 или 3 & -1 & 0,09 & \\
\hline \multirow[t]{2}{*}{3} & \multirow{2}{*}{$\begin{array}{l}\text { Содержание гемоглобина в эритроците, } \\
\text { г/л }\end{array}$} & $<117$ & +4 & 0,97 & \multirow[t]{2}{*}{2,03} \\
\hline & & от 117 & -5 & 1,06 & \\
\hline \multirow[t]{2}{*}{4} & \multirow[t]{2}{*}{ Мочевина в крови, ммоль/л } & $\leq 8,3$ & -2 & 0,18 & \multirow[t]{2}{*}{0,48} \\
\hline & & $>8,3$ & +3 & 0,30 & \\
\hline \multirow[t]{2}{*}{5} & \multirow[t]{2}{*}{ Крсатинин кровн, мкмоль/л } & $\leq 115$ & -2 & 0,43 & \multirow[t]{2}{*}{1,46} \\
\hline & & $>115$ & +6 & 1,03 & \\
\hline \multirow[t]{2}{*}{6} & \multirow[t]{2}{*}{ Холестернн крови, ммоль/л } & $\leq 3,4$ & +11 & 3,91 & \multirow[t]{2}{*}{5,91} \\
\hline & & $>3,4$ & -6 & 2,00 & \\
\hline \multirow[t]{2}{*}{7} & \multirow{2}{*}{$\begin{array}{l}\text { Уровснь липопротеидов низкой плотно- } \\
\text { сти в крови, ммоль/л }\end{array}$} & $<1,8$ & +5 & 1,40 & \multirow[t]{2}{*}{2,70} \\
\hline & & $\geq 1,8$ & -5 & 1,30 & \\
\hline \multirow[t]{2}{*}{8} & \multirow{2}{*}{$\begin{array}{l}\text { Уровснь липопротеидов нысокой плот- } \\
\text { ности в крови, ммоль/л }\end{array}$} & $<1,2$ & +4 & 0,74 & \multirow[t]{2}{*}{1,62} \\
\hline & & $\geq 1,2$ & -4 & 0,89 & \\
\hline \multirow[t]{2}{*}{9} & \multirow[t]{2}{*}{ Аланинаминотрансфсраза, Ед/л } & $<12,5$ & +12 & 3,64 & \multirow[t]{2}{*}{5,06} \\
\hline & & $\geq 12,5$ & -5 & 1,42 & \\
\hline \multirow[t]{2}{*}{10} & \multirow[t]{2}{*}{ Креаинфосфокиназа общая, Ед/л } & $<110$ & -4 & 1,34 & \multirow[t]{2}{*}{4,34} \\
\hline & & $\geq 110$ & +10 & 2,99 & \\
\hline \multirow[t]{2}{*}{11} & \multirow[t]{2}{*}{ МВ фракция креатинфосфокиназы, Ед/л } & $<15$ & -1 & 0,04 & \multirow[t]{2}{*}{0,09} \\
\hline & & $\geq 15$ & +1 & 0,05 & \\
\hline
\end{tabular}

Прнмечание. Положительный прогностический козффнциент свидетсльствует о прогнозировании проявления цитопротекторного свойства цитоф.лавина у пациснта, отрицательный прогностический коэффициент свидетельствует о прогнозировании отсутствия прояв.ения цитолротекторного зффекта цитофлавнна. 
ченной из крови пациентов с ИБС, наблюдалось два варианта измснения жизнсспособности клеток: у большинства $(80 \%)$ больных отмечсно увеличение жизнеспособности лейкоцитов в срелнем на $60 \%$ $(p<0,001)$ и у $20 \%$ - тснденция к уменьшению данного показателя в среднем на $47 \%(p<0,1)$.

2. Выявлен ряд условий исходного состояния пациента с ИБС для проявления цитопротекторной активности цитофлавина: первая степень сопутствующей артериальной гипертснзии; нормальный (невысокий) уровень липидов в крови - общего холестерина в сыворотке крови (менсе 3,4 ммоль/л), липопротеидов очень низкой пллотности (менсе 1,8 ммоль/л) и липопротеидов высокой плотности (менее 1,2 ммоль/л), гіризнаки разрушения миоцитов и кардиомиоцитов (увеличение уровня КФК общ. в крови болес $110 \mathrm{Eд/л}$ и МВ-фракции КФК болсе 15 Ед/л), нормальная функция печени (по уровню АЛТ менее 12,5 ЕД/л), признаки нарушения функции почск (повышение уровня мочевины - болес 8,3 ммоль/л и креатинина крови более 115 мкмоль/л), снижснное содержанис гемоглобина в эритроцитах (мснсе 117 г/л) как косвенный признак гипоксии органов и тканей и состояние активации функциональной адаптационной системы чсловека (ю данным общего анализа крови - появјсния базофилов более $0,1 \cdot 10^{\varphi} /$ л).

3. Фснотипический профиль пациснтов, у которых введснис питофлавина in vitro в терапевтической концентрации ассоциировалось со снижснием жизнеспособности клеток, характеризуется: высокой степенью артериальной гипертснзии, повышенным уровнем липидов крови, истошснием функциональных резервов систсмы адаптации, нарушенной функцией печсни при отсутствии признаков системной гипоксии, разрушения клеток ссрдца, скелетных мышц и почск.

\section{Благодарность}

Авгор выражает свою искреннюю благодарность директору НИИ фармакологии живых систем НИУ "БелГУ" профессору, д.м.н. М. В. Покровскому и руководителю лаборатории клеточных технологий НИИ фармакологии живых систем доценту, к.б.н. С. В. Надеждину за прсдоставленную возможность выюлнения исслсдования на базс указанной лаборатории. Автор также выражает свою признательность заведующему отделением кардиологии № 1 доценту, к.м.н. П. К. Алфёрову за оказаниое содействис при наборе клиничсского материала для исследования и доценту, к.т.н. В. В. Румбешту за помощь в статистической обработке данных.

\section{ЛИТЕРАТУРА}

1. Е. И. Асташкин, М. Г. Глезер, Клии. геронтол., 11, 3-10 (2008); УДК 612.013.I=612.67

2. Л. Х. Гаркави, Е. Б. Квакина, Т. С. Кузьмснко, Антистрессориье реакции и активациопная терапия, Москва (2015).

3. М. Г. Глезер, Ю. А. Карпов, Н. Б. Псрспеч и др., Am.иосфера. Новости кардиологии, 4, 21 - 26 (2019); doi: 10.24411 2076-4189-2019-12171

4. П. Р. Камчатнов, Б. А. Абусусва, М. А. Евзельман и др., Доктор. $P_{y}, 161(6), 23-26$ (2019); doi: 10.31550 1727-2378-2019-16]-6-23-26

5. П. М. Ларионов, А. Н. Малов, М. М. Мандрик и др., Журн. приктадной спектроскоп., 70(1), 38 - 42 (2003); doi: 10.1023 A: 1023212206592

6. Г. А. Ливанов, А. Т. Лоладзе, А. Н. Лодягин и др., Эксnерии. и кин. фариакол., 80(6), 30 - 33 (2017); doi: 10.30906 / 0869-2092-2017-80-6-30-33

7. Е. В. Митрошина, Т. А. Мишенко, М. В. Ведунова, Определение жизнеспособности ктеточиых культур. Учебио-меmодическое пособие, Нижний Новгород (2015).

8. М. В. Покровский, О. В. Ромашенко, С. В. Надеждин и др., Способ определения цитопротекторного свойства у лекарственияго nрепарата. Cвидетельство о ноу-хау № $336 \mathrm{om}$ 9.11.2020, Белтород. НИУ "БелГУ".

9. О. В. Ромащенко, Эксперии. и киин. фармакол., 81(6), 14 - 19 (2018); doi: $10.30906 / 0869-2092-2018-81-6-14-19$

10. О. В. Ромащенко, Эксперия. и клин. фариакол., 82(1), 16 - 21 (2019); doi: 10.30906 0869-2092-2019-82-1-16-21

11. О. В. Ромашенко, Јксперии. и киин. фармакол., 84(3), 17 - 21 (2021); doi: 10.30906/0869-2092-2021-84-3-17-21

12. Цитофлавин. Рег. Удостоверение № P N003135 / 01-220319.

13. Л. Б. Узенбаева, А. Г. Кижина. В. А. Илюха и др., Известия Российской Академии назк. Сер. биол., 46(4), 398-406 (2019); doi: 10.1134 /S0002332919030135

14. L. H. Brubaker, L. J. Essig, Blood, 50, $657-662$ (1977); PMID: 901939

15. R. Ferтari, P. Camici, F. Crea, et al., Nat. Rev. Cardiol., 15, 120 - 132 (2018); doi: $10.1038 /$ nrcardio.2017.131

16. W. Jin, G. Deng-Feng, W. Hao, et al., PLOS ONE Dec 3/, 9(12), c116239 (2014); doi: 10.1371; journal.pone.0116239. eCollection 2014

17. J. Knuuti, W. Wijns, A. Saraste, ct al., European Heart J., 41, 407 - 477 (2020); doi: 10.1093 / curheartj / ehz425

18. S. K. Zyryanov, S. B. Fitilev, A. V. Vozzhaev, et al,, Research Results in Pharmacol., 6(3), 15-20 (2020): do: 10.3897 . rrpharmacology.6.53615

\section{POSSIBILITY OF PERSONALIZED USE OF CYTOFLAVIN AS CYTOPROTECTIVE AGENT IN CORONARY HEART DISEASE}

\section{o. V. Romashchenko}

Belgorod State National Research University, ul. Pobedy 85, Belgorod. 308017 Russia

Possibility of the personalized use of cytoflavin in patients with coronary heart disease (CHD) was studied based on the criteria for predicting the cytoprotective activity of this drug during in vitro testing of its effect on cell viability. We examined a group of 30 patients with $\mathrm{CHD}$ diagnosis. including stable angina pectoris of I-III functional classes with concomitant anerial hypertension (AH) and chronic heart failure. Patients underwent general and biochemical blood tests with determination of cholesterol profile, creatine phosphokinase (CPK) total and MF-fraction. and renal and hepatic complexes. To determine the cytoprotective activity of cytoflasm, blood leukocytes of patients were examined in vitm by fluorescence microscopy using Eclipse Ti-U inverted fluorescence microscope 
(Nikon, Japan). Living and dead cells were determined by staining leukocytes with fluorescent dyes (Calcein AM. ethidium bro-it $\mathrm{L}=\mathrm{a}$ the oell viability (IL) index was calculated. The data were statistically processed and the criteria for predicting the cytoprotective effect of cylotan $=$ ace decermined using the Wald's prognostic analysis. When cytoflavin was injected into a sample with a leukocyte suspension, two variants of changes in cell vel, 7 were observed: (i) in $80 \%$ of patients, the IL value increased (on the average, by $60 \%, p<0.001$ ) and (ii) in $20 \%$ of patients, the IL decreased (on the anerese by $47 \%, p<0.1$ ). Conditions of the initial state of patients with CHD for the manifestation of cytoflavin cytoprotective activity were identified as follows the firs degree of concomitant arterial hypertension; normal (low) blood lipids with total serum cholesterol (less than 3.4 mmoll. ven low densen lipoproteins (less than $1.8 \mathrm{mmol} / \mathrm{L}$ ) and high density lipoproteins (less than $1.2 \mathrm{mmol} / \mathrm{L}$ ), signs of destruction of myocytes and cardiomyocytes (increase in the level of total CPK in the blood more than $110 \mathrm{U} / \mathrm{L}$ and the CF fraction of CPK mo:e than $15 \mathrm{U} / \mathrm{L}$ ), normal liver function (by ALT level less than $123 \mathrm{C}$ L) sagns of dysfunction (increase in the level of urea more than $8.3 \mathrm{mmol} / \mathrm{L}$ and blood $\mathrm{k}$.dney creatinine more than $115 \mu \mathrm{mol} / \mathrm{L}$ ); reduced content of hemoghobm in enthrocytes (less than $117 \mathrm{~g} / \mathrm{L}$ ) as indirect signs of hypoxia in organs and tissues and the state of activation of the functional adaptive system of a patent (acoording to the general blood test, the appearance of basophils at counts above $0.1 \cdot 10^{9} \mathrm{l} / \mathrm{L}$ ). According to the results of in vitro study, cytoflavin exhibits croprotective activity by increasing cell viability in $\mathbf{8 0} \%$ of CHD patients, provided there is an individual pharmacodynamic target for the action of this drug: signs of destruction of myocytes of skelctal muscles and heart, renal dysfunction, systemic hypoxia against the background of normal blood lipids, intact liver function, the first degree of arterial hypertension and the activation phase of the human functional adaptation system. These factors determine the possibility of personalized use of cytoflavin in CHD patients.

Keyw ords cytoflavin; leukocytes; viability; coronary heart disease; patients; microscopy; in vitro study; personalized pharmacotheraps. 